\title{
ISLAM IN REDEFINING A DIFFERENCE
}

\author{
Agus Hermanto \\ Universitas Islam Negeri (UIN) Raden Intan Lampung, \\ Email: gusher.sulthani@radenintan.ac.id.
}

\begin{abstract}
:
"Islam in Redefining A Difference". Islam is a religion rahmatanlil'alamin, for that Islam can put the situation and conditions. Islam is the religion Hanif, fairness and tolerance to their ikhtilaf (dissent). In terms of the causes and roots, there are two forms ikhtilaf (dispute), the deviation caused by the character and thought. Unjustified deviation is a deviation in aqidah matter of principle. Deviation is actually a little touch on the basic framework of worship. However, when the jurists began to enter the technical and operational principle that no deviation is irreversible appearance. Deviation can be justified is the deviation in trouble furu', and the issue is not the principle I'tiqad. Deviation different from the iftiraq, iftiraq according to the language comes from the word meaning mufarawah division and separation. Meanwhile, according to the terms of the scholars, iftiraq is out of the Sunnah and Jama'ah on one ushul (principal) of a judge actions ushul fundamental, both in aqidah or amaliyah.
\end{abstract}

Keywords: Islam, Difference

\begin{abstract}
Abstrak:
"Islam dalam Mendefinisikan Kembali Perbedaan". Islam adalah agama rahmatanlil'alamin, untuk itu Islam dapat meletakkan situasi dan kondisi. Islam adalah agama Hanif, keadilan dan toleransi terhadap ikhtilaf mereka (perbedaan pendapat). Dari sisi penyebab dan akarnya, ada dua bentuk ikhtilaf (perselisihan), penyimpangan yang disebabkan oleh karakter dan pemikiran. Penyimpangan yang tidak dapat dibenarkan adalah penyimpangan dalam hal prinsip aqidah. Penyimpangan sebenarnya sedikit menyentuh pada kerangka dasar ibadah. Namun, ketika para ahli hukum mulai memasukkan prinsip teknis dan operasional bahwa tidak ada penyimpangan penampilan yang tidak dapat diubah. Penyimpangan yang bisa dibenarkan adalah penyimpangan dalam kesulitan furu ', dan masalahnya bukan prinsip I'tiqad. Penyimpangan berbeda dari iftiraq, iftiraq menurut bahasa berasal dari kata mufarawah yang artinya pembagian dan pemisahan. Sementara itu, menurut ketentuan para ulama, iftiraq berada di luar Sunnah dan Jama'ah atas satu ushul (pokok) dari tindakan hakim ushul mendasar, baik dalam aqidah atau amaliyah.
\end{abstract}

Kata kunci: Islam, Perbedaan

\section{A. Introduction}

Religious mission is to free humanity from the form of injustice, because Islam1 is rahmatan li al-'alamin (protect the entire universe), a tolerant religion of the whole affair. If there is a value that is not in line with the principles of justice, it is necessary reactualizationinterpretation with two things: read the book

1Masdar F. Mas'ud, Islam and Women's Reproductive Rights, revised edition, cet. 1, (Bandung: Mizan, 2010), p. 197. Abdul Mustaqim, Reading Feminist paradigms Tafsir al-Qur'ân with Optics Woman Thought About RiffatHasan on Gender Issues in Islam, (Yogyakarta: Logung Reader, tt.), p. 1314. Yaswirman, Family Law, (Jakarta: Rajawali, 2004), p. 124 
comprehensively or need to be considered, namely the human perception in defining a concept of justice. ${ }^{2}$

In the past decade, the issue of religion and conflict sounded so fast. A convergence between religious and political interests mean misused and abused by a group of persons, both religion and politicians, leading religious cornered negative position; religion or unrest source of violence, but religion is not at all related to the conflict, violence, even though radicalism. Followers which causes the fall pit, the defendant's religion.

If religion does not matter to religions, fully understand the teachings contained religious beliefs, undoubtedly disaster or conflict that religion never happened. Therefore, no single religion that teaches contention, but rather religion is a source of inspiration for justice and tolerance and inter-religious neighbor to though.

\section{B. Nature of Islam}

Islam comes from the word aslamayuslimuIslaman and is picked up from the root word salimayaslamu shake wasalamatan, which literally means peace, happy, prosperous, obey, submit and surrender. ${ }^{3}$ Islam also usually defined as a revelation, as follows; al-Islam wahyunilahiyununzilaila alnabiyyiMuhammadinAllaahwaAhaihisallamalisa'adati al-dunyawa al-akhirah (Islam is a revelation to the Prophet Muhammad as a guide for the happiness of living in the world and the hereafter. ${ }^{4}$

The Qur'an itself which is about 137 times inSalama said that one idea including her use of the word Salama / Islam for several meanings. Among them surrendered to Allah as contained in paragraph:

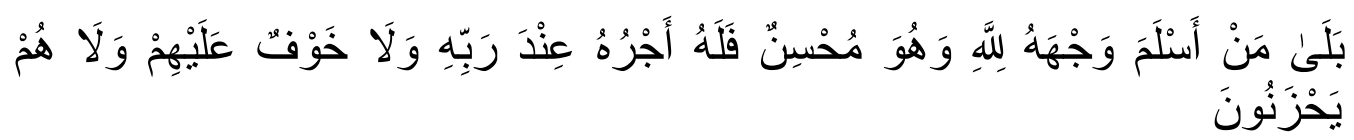

It means: "(not) even Whoever surrender to God, was he doing good, then his reward with their Lord, and no fear come upon them and not (also) they grieve." (QS. AlBaqarah: 112).

In accordance with the din and said mean etymologyal-Islam, the scholars' whom Muhammad Syaltut, formulate; Din al-Islam is the religion of Allah that he arrange to teach the basics and Shari'ah-His Shari'ah to the Prophet Muhammad and freeing (assigning) to the Prophet Muhammad., In order to convey to the whole of humanity and called on the al- Islam. ${ }^{5}$

Noting sense of the word din coverage is so comprehensive, flexible and even comprehensively, it is easily understood if some scholars of Islam such

\footnotetext{
2Hasyim, Umar. Toleransidankemerdekaanberagamadalam Islam sebagaidasarmenuju dialog dankerukunanantar agama: sejarahtolerasi [ietoleransidanintoleransi agama dankepercayaansejakjaman Yunani. BinaIlmu, 1979.

3WarsonMunawwir Muhammad, Al-Munawwir, (Surajaya: Progressive Library, 1997), p. 654

${ }^{4} \mathrm{M}$. AthoMuddzhar, Approach Islamic Studies in Theory and Practice, (Yogyakarta: Student Library, 2011), p. 19

5Faridah, IkaFatmawati. "ToleransiAntarumatBeragamaMasyarakatPerumahan." Komunitas: International Journal of Indonesian Society and Culture 5.1 (2013).
} 
us SidiGazalba not agree identifies religion with the din. According to him, the vagueness and confusion religious sense arising from the use of terms that are used in other religious belief systems of Islam, which between them lie in the differences. Hinduism, Buddhism spread the word religion in the archipelago, was taken over by the Malay, in island Indonesia, followed by the Indonesian in the history of the archipelago one when Islam came and Hinduism? Buddhism went to demand the new credential, society Nusantara Malay language, using the word religion is also (besides of Religious and religion), which had been borrowed from Sanskrit. ${ }^{6}$

Unlike the SidiGhazalba, EndangSyaifuddinAnsyari, seemed to accept any religious statement on the one hand and on the other hand din. According to Religion religious and din each does have its own etymological meaning and have a history and history alone. But in the sense that the term third tennisterminology core has the same meaning. Furthermore, he said: "Religion is equivalent (synonyms) with din. Called din not only in Islam, but also in addition to the Koran.

Sidi Ghazalba statements concerning certain things are not legitimate; but what is proposed ES. Ansari also has a point. Because, in fact the Qur'an says din is not always associated with al-Islam. Absolutely Most said al-din din used with the meaning associated with the religion of Islam, but there is also the word din used in conjunction with other religions.

Word of Allah:

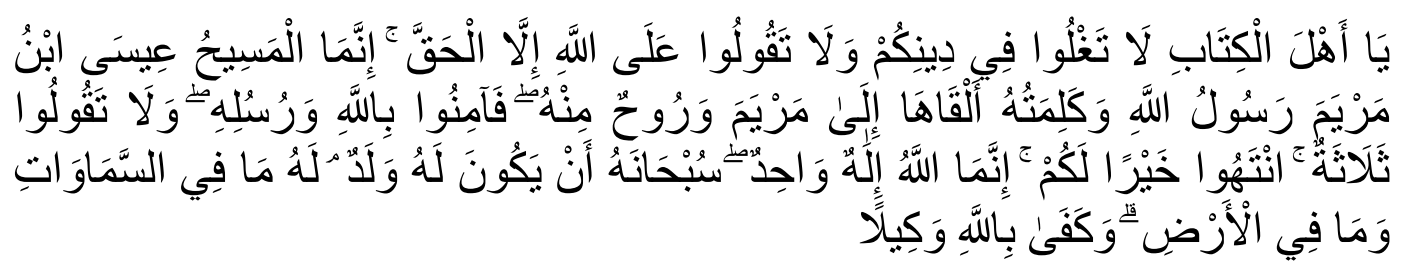

It means: "O People of the Book, do not transgress limits in religion, nor say of Allah except the truth. Indeed, the Messiah, Jesus son of Mary, the Messenger of Allah and (created by) his sentence conveyed unto Mary, and (with a gust) spirit from Him. So believe in Allah and His Messengers and do not say: "(God) three" stop (from the speech). (It is) better for you. Verily Allah Almighty God, the Most holy God of having children, everything in the heavens and Earth belongs to Him. enough is Allah became the Sustainer". (QS. Al-Nisa ': 171).

As also described in the letter of al-Kafurun paragraph 6. Likewise millah word which also means religion or muraddif (synonyms) with the word din. Said Milla is not always related to the Islamic religion in this case religion of Abraham, as in many verses of the Qur'an, among others, the letter al-Baqarah verse 130, and 135 of Ali Imran paragraphs 130 and 163 al-An'am verse, but there also associated with the religion of the Jews and the Christians. As in surat alBaqarah verse 120:

6M. AthoMuddzhar, Approach Islamic Studies in Theory and Practice, (Yogyakarta: Student Library, 2011), p. 19 


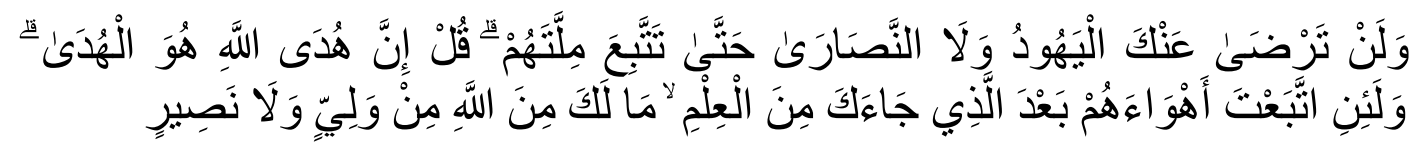

Meaning: "The Jews and Christians will not be pleased to you until you follow their religion. Say: "Verily Allah That user manual (which is true)". and Truly if you follow their desires after the knowledge came to you, then God is no longer the protector and helper for you. "(QS. Al-Baqarah: 120).

Differences of opinion among scholars on the definition of din al-Islam etymologically nor terminologies, will not affect the breadth, flexibility and excellence of this religious teachings of the Islamic religion whichever. Openness to be researched, discussed, compared and even if to be compared, implies superiority of this religion. Of course if it is Islam, condition is the teaching-din al-Islam, not the wrong thing muslimin the culture. Because the reality is not that sharp little difference even contradictory between al-din al-Islam theoretically (teachings) with the culture of the Muslims in the practice of their daily lives.7

\section{Meaning Difference (Deviation)}

The difference (deviation) in the language is at odds, not one ide. While the terminological deviation are misunderstandings or opinions among the scholars to seek truth. Khilafiyah problem is a problem that occurs in the reality of human life. Among khilafiyahproblem exists that finish in a manner that is simple and easy, because there is a mutual understanding based on common sense. But behind it khilafiyah can establish a wedge issue to establish harmony among Muslims, because the attitude $t a^{\prime} \operatorname{ssuf(fanatic)}$ is excessive is not based on common sense and so on. ${ }^{8}$ In terms of the causes and roots, there are two formsikhtilaf (disputes), which is caused by moral deviation and deviation caused by thought.

\section{C.1. Tang deviation caused by factors morals}

Deviation arising because of the character is known by scholars and murabbi (builder) that takes into account various attitudes and motivations of the various events. Among the causes are as follows:

a. Pride and admiring his own views.

b. Prejudice to others and is easier to blame others without proof.

c. Egoism and debauched; consequently between the ambitions of the leadership or positions.

d. Fanatical about people's opinions, sects and groups.

e. Bigots to country, region, party, or the leader of the congregation.

All of it is a despicable character and muhlikat (thing disgraceful) and the views of the scholars 'kitub (ulama' who investigate matters of the heart). Obligatory upon Muslims and Islamic activists moreover lay preachers to try to avoid properties that are reprehensible. Deviation arising from the reprehensible

7Muhammad Amin Suma, Religious Pluralism According to the Koran Tela'ahAqeedah and Shari'ah, (Jakarta: PustakaFirdaus, 2001), p. 70-74

8Syaikhu, School of Comparative Jurisprudence, (Yogyakarta: AswajaPressindo, 2004), p. 24 
jewelry this is a dispute that is not commendable, even including splits the blame.9

\section{C.2. The deviation caused by factors thought}

This deviation arises because different points of view on an issue, either natural or problems amaliah problems. The examples in the scientific problem are a difference on issues of aqidahShari'ah and some problems that do not touch the principles of certainty. As for the problem of 'amaliyah is the difference about political attitudes and decision-making on various issues, creed, different points of view, the completeness of data and information, environmental influences and age.

Among the most noticeable is the difference in the congregation-Islamic congregation against political attitudes in our own time. Such as participation in elections, get into parliament, participation does not commit the government in the implementation of Islamic Shari'a,coalition to force non-Muslims to overthrow the government does not give the freedom of opinion at all, and so forth. Most of the deviation purely political nature, namely with regard to the consideration of the benefit and danger, between achievements and losses, present and future.10

\section{Basic Concepts of Tolerance}

Tolerance etymologically is the nature and attitude appreciate, omission. Could mean also the willingness to want to understand the real face is different from the familiar embraced own. Generally speaking, tolerance is an attitude of respect for others. In Lisan Al-Arab IbnMandur common sense; Musammah is to oversimplify or light attitude, as in the hadith which means: "Being light it will bring benefits to the owner of the attitude that".

Understanding tasammuh we encounter the texts of the Koran, hadith, and sira of the Prophet. AgreementMadinah (Medina Watsigah) called by the Prophet., As the basis of living together or coexistence among the entire population of Medina, regardless of religion, ethnicity and race, a clear picture of Islamic tolerance toward mankind in general. Nature was reinforced by the personal traits of the Prophet. And his companions. Word-his saying were so many matching with such attitudes, such as the hadith.

"By the One (God) that my soul is in power him, God did not put (deliver) mercy except to the people who are affectionate. The friend said: "Each of us is love". The Prophet said: "It was not just compassion to fellow comrades, but to love all mankind".

The hadith is not only fostering tolerance us to do, but it requires us to do compassion for fellow human beings. Many verses of the Qur'an direct Muslims to be tolerant towards others, and instead implement the attitude is considered as a way to attract sympathy.

${ }^{9}$ Yusuf Qaradawi, The Islamic Figh Opinion Difference Between Muslim Neighbor, (Jakarta: Robbani Press, 1990), p. 18

10Ibid., p. 19 
As stated in the letter al-Fussilat:

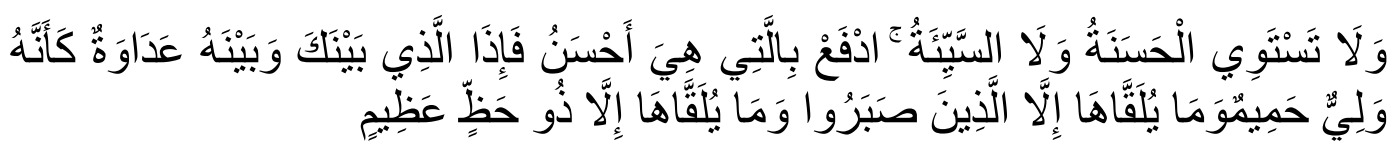

It means: "And not equal good and evil. Repel (evil) with a better way, then suddenly people among and between him no hostility seems to have become a very loyal friend. The properties are good it was not granted, but to those who are patient and do not conferred but to people who have a big advantage. "(QS. Al-Fussilat: 34-35).

Rejecting the evil of others with a better way is accompanied by patience and tolerance in the sense of not returning evil for evil, even stick to the norms of religion and virtue, be of great value to those who opposed or hostile.

The tolerant attitude of course requires a great heart, which full with affection, despite being able to reply. The ability to reply even this must, so that the opposing party does not consider it a weakness. Thus, it is clear that the Muslims should be strong in upholding the principles of his religion then coupled with an attitude of tolerance. As explained in the letter al-Mumtahanat:

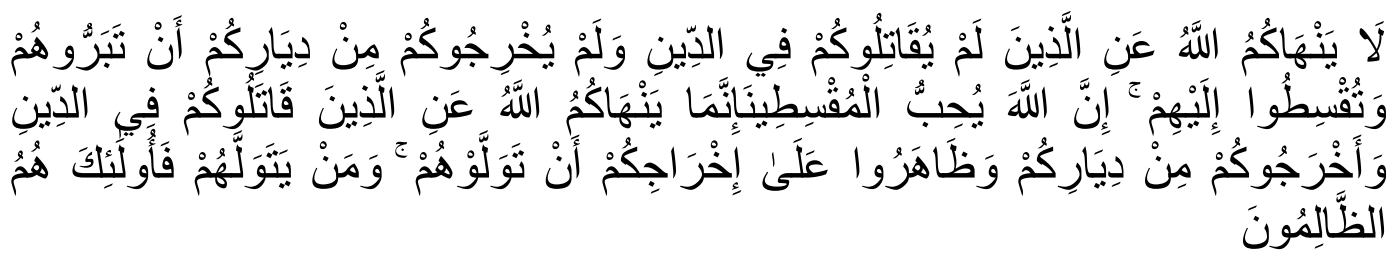

Meaning: "Allah does not forbid you from being good and Be fair to those who fight you because of religion and not (also) expel you from your homes. Allah loves those who are fair Applicable. God only forbids you from taking as friends those who fight you because of religion and expel you from your homes and support (others) expulsion. and whoever made them as a friend, then they These are the people who do wrong. "(QS. AlMumtahanat: 8-9).

Two verses in addition to be gentle and tolerant, even non-Muslims to be kind to who does not act of hostility against the Muslims, and this is the rules of the relationship between Muslims and non-Muslims clearly and so fair. If Christianity is proud of his religion as the religion of love: "When people get hit on the left cheek, then hand over the right cheek". Then we Muslims are proud with the guidance of Allah:

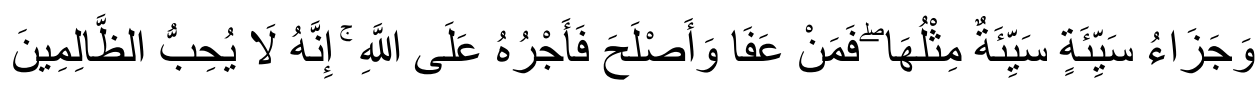

Meaning: "May we follow Sorcerers if they are the ones who win" (QS. Al-Shura: 40).

This is the basis of reciprocity, including the ugly must repay with evil, with the intention of revealing the strengths and abilities, so maker ugliness is not prolonged in doing evil. However, we remain focused on forgiveness with the intention of seeking forgiveness and good pleasure of Allah, cleanse the soul 
of envy and remove mutual hostility and resentment. doer crime, if knowing that we are strong and able to retaliate, but instead we pardon, then they will be ashamed of themselves and downs of bad deeds.

Forgiveness should be coupled with the ability to retaliate. This attitude is expected to bring peace and tolerance. With thereby, the person who committed the crime feel that the pardon was brought tolerance and feel will feel ashamed of themselves. Even more verses that reinforce toe ran attitude both to friend and foe alike.11

\section{E. Substance Understanding Islam}

Living in the State of Indonesia as a multiethnic and multicultural very demanding collective consciousness in maintaining mutual respect and appreciate. Muslims as a component of the nation, most assume responsibility in fighting for the values of Islam as peaceful and as much as possible to avoid violent means. Sociologically, the ways of life that promote tolerance and peace is believed to be a determinant variable for the creation of national interties. In this context, Muslims can contribute by making Islam as a patron and protector of others, especially for minorities.

As a consequence, Muslims are required to develop attitudes that are more mature when actualize religious. Adult attitude of Muslims in religious indicated by approaching Islam from the deepest, essential, substantial, or sought idea fundamental than merely debating things that arefuru'iyyah or instrumental. In eksiologis, value-laden Islam arises from the fundamental teachings of values (core values) as the value of faith, the pillars of Islam, and charity as well as instrumental value (values devices) like a traditional society, politics and the like.12

The issue of terrorism has always been associated with Islam, and the Muslims. Terrorist acts are rampant here and there have been many casualties, bombing several regions, plane hijacking, bombing public places, is partly an act of terrorism is a very scary and claimed thousands of lives without knowing the age, sex, sin, or not sin. Most of the victims instead of the Muslims. Obviously, terrorism detrimental to all parties. Unfortunately, the diverse events and the perpetrators of terrorism brain addressed to Islam does not teach things, according to his people, let alone encourage them to such barbarity.13

Islam and the conception of the teachings of Rabbani, always clear and fundamental view of history or events, not merely look at the relationship between human beings on the ground foraging and racial clashes; however, Islam established the relationships between people on the basis of unity and to serve the Lord.

Indeed, in the body there is a dispute Muslims ,. However, the dispute was not a racial strife as was interpreted by commentator's ignorance for their own interests. The struggle within Islam, merely a struggle between the right and falsehood; good and bad. As affirmed in the Qur'an, "If there is no rejection of

11AsyhariMarzuki, Reaching Life Insights Qur'anic Islam, (Yogyakarta: Nurma Media Idea, 2003), p. 3-9

12Zubaidi, Islamic Rule and Inter-Civilization, (Yogyakarta: Al-Ruzz Media Group, 2007), p. 73

13Shaikh Abdullah bin Abdul Aziz bin Baz, Fatwa-Fatwa Regarding Terrorism, (Jakarta: Pustaka al-Tazkia, 2004), p. 14 
God over most of human malignancies with others, certainly corrupted the earth" (QS. Al-Baqarah: 251).

Islam does not encourage humans echoed yell "nationalism". Establishment of Islam in this matter is clear, because Islam does not prohibit the commonwealth of diverse race. Islam does not require the State Egypt for example, so that they hold their nationalism as the Egyptians. Islam does not demand the Arabs releasing existence. Islam does not encourage the Indians to undress as the Indian nation. But more than that, Islam put forward a concept:

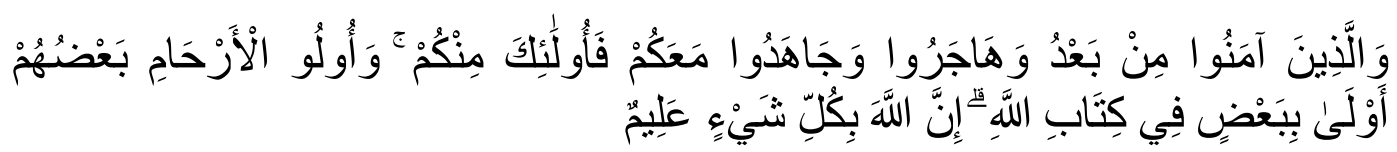

Meaning: "But those were included yours group (too). people who have relatives relationship was partly more right toward each other (than not relatives) in the book of Allah ". (QS. Al-Anfal: 75).

Thus Islam establishes relations blood when bond linkage and linkage above the banner of Islam, Muslims cheer. But, when conflicts and struggles, which led to the curtains insulation between the elements of the body of Muslims with other elements, then it is called a dark bigotry. As noted the intent of the words of the Prophet. "Leave bigotry, because it is a stench". In another hadith mentioned:

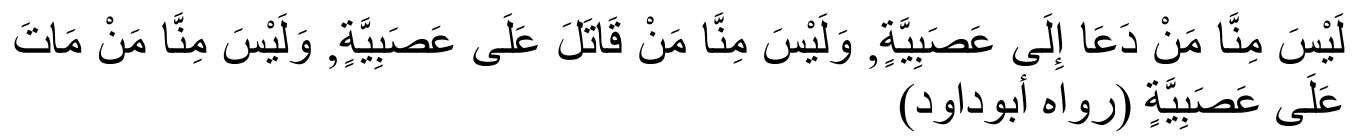

Meaning: "It is not from our group of people who took bigotry. Not from our group who fought on the basis of bigotry. And not from our group of people who die on the basis of bigotry ". (HR. Abu Daud).

Presumably it is enough for us to present a general overview about the conception of Islam. We do not discuss ideas or conceptions of Islam as an alternative to other ideologies. Because the only alternative is Islam itself. We do not discuss ideas of Islamic thought as a stand-alone, because Islam does not recognize a thought that does not switch on behavior. We are simply discussing the Islamic concept or dimension of Islamic thinking to help us to attempt again to discuss Islam in the era of isolation in the midst of his people.

Then it should we are trying to practice Islam in everyday. We save and make use of the human side of this with what is inherent in Islam. Therefore, only Islam alone can save. Only Muslims can give benefit to the world and everything in it. Muslims will not be able to provide humanitarian values, until they realize Islam first by setting a solid faith in their souls. ${ }^{14}$

14Muhammad Qutthb, Islamic Personality Modernization In the Arena, (Surabaya: RisalahGusti, 2004), p. 97-92 


\section{F. Differences a Grace (Rahmat)}

Among the in-depth knowledge that is forgotten by some people who are steadfast in religion is the knowledge of the levels of shari'a law, and that not all of them are at the same level in strength, as well as in disputing him.

Many laws are dhanni (conjectures and not certain) that a ban on jihad and has a wide range of possibilities for understanding and interpretation. Whether it's the laws that no texts in it, and in which there are nashdhanni, in its essence, or understanding, or in both simultaneously. It is the nature of most of the laws relating to deeds, like the laws of jurisprudence. In this case, quite the arguments dhanni, not as matters relating to the creed that require definite and convincing proposition.15

Ikhtillaf (dissent) in laws furu'surely that is dhanninot cause any harm and danger for ijtihad basedsyar'i correct. This is actually a blessing for the people, show flexibility in the Shari'ah, and the breadth of knowledge and understanding. Friends and tabi'in often quarrel in various legal furu'but such was not the slightest harm him and not the slightest crack their friendship.

There are also some law set Qur'an, hadith and ijma' (agreement ulama) and has achieved a degree of certainly (definitive) although he tudak becomes dharuri (may not be so) in religion. These things describe the unity of mind and behavior of people. Who break means breaking the sunnah-sunnahof the Prophet., And daat referred to as the perpetrator of evil, heretical, and sometimes to the extent of $k u f r$.

Thus, one does not translatedput legal framework and level of course that some people are in a hurry attaching designation infidels or wicked or heretics to everyone that invalidates one of any law, solely on account of his famous law was among the prosecution of science; or often referred to in books without distinguishing between multiple ushul and Firu', between set by nas or set by ijtihad, among which certain ( $\left.q a d h^{\prime} i\right)$ is uncertain (dhanni) in the texts, as well as things to be done and that not in religion, while each has a notch and its own laws.16

\section{G. Conclusion}

Islam is a religion rahmatanlil'alamin, for that Islam can be put anywhere and anytime. Islam is the religion Hanif, fairness and tolerance to their khktilaf (dissent). In terms of the causes and roots, there are two forms ᄀikhtilaf (disputes), which is caused by moral deviation and deviation caused by thought. Unjustified deviation is a deviation in aqidah matter of principle. Deviation is actually a little touch on the basic framework of worship. However, when the jurists began to enter the technical and operational principle that no deviation is irreversible appearance. Deviation can be justified is the deviation in trouble furu', and the issue is not the principle I'tiqad. Deviation different from the iftiraq, iftiraq according to the language comes from the word meaning mufarawah division and separation. Meanwhile, according to the terms of the scholars, iftiraq is out of the Sunnah and Jama'ah on one ushul (principal) of a judge actions ushulfundamental, both in aqidah or amaliyah.

\footnotetext{
15Ismail, Roni. "KonsepToleransidalamPsikologi Agama (TinjauanKematanganBeragama)." ReligiJurnalStudi Agama-Agama 8.1 (2012): 1-12.

16Yusuf Qaradawi, The Islamic Dissecting Extreme, (Bandung: Mizan, 2001), p. 158
} 


\section{Bibliography}

Abdul Mustaqim, Reading Feminist paradigms Tafsir al-Qur'ân with Optics Woman Thought About RiffatHasan on Gender Issues in Islam, Yogyakarta: Logung Library, tt.

AsyhariMarzuki, Reaching Life Insights Qur'anic Islam, Yogyakarta: Nurma Media Idea 2003

Faridah, IkaFatmawati. "ToleransiAntarumatBeragamaMasyarakatPerumahan." Komunitas: International Journal of Indonesian Society and Culture 5.1 (2013).

Hasyim, Umar. Toleransidankemerdekaanberagamadalam Islam sebagaidasarmenuju dialog dankerukunanantar agama: sejarahtolerasi [ietoleransidanintoleransi agama dankepercayaansejakjaman Yunani. BinaIlmu, 1979.

Ismail, Roni. "KonsepToleransidalamPsikologi Agama (TinjauanKematanganBeragama)." ReligiJurnalStudi Agama-Agama 8.1 (2012): 1-12.

Masdar F. Mas'ud, Islam and Women's Reproductive Rights, revised edition, cet. 1, Bandung: Mizan, 2010

M. AthoMuddzhar, Approach Islamic Studies in Theory and Practice, Yogyakarta: Pustaka Student 2011

Muhammad Amin Suma, Religious Pluralism According to the Koran and the shari'aTela'ah Creed, Jakarta: PustakaFirdaus, 2001

Muhammad Qutthb, Islamic Personality Modernization In the Arena, Surabaya: RisalahGusti 2004

WarsonMunawwir Muhammad, Al-Munawwir, Surajaya: PustakaProgressif, 1997

Pius A Partanto, Dictionary of Popular Ilmia, Surabaya: Arkola, 1994

Shaikh Abdullah bin Abdul Aziz bin Baz, Fatwa-Fatwa Regarding Terrorism, Jakarta: Pustaka al-Tazkia 2004

Syaikhu, School of Comparative Jurisprudence, Yogyakarta: AswajaPressindo 2004

TarmiziTaher, Islam Moderate, Jakarta: GrafindoKhozanah Science 2007

Yaswirman, Family Law, Jakarta: Rajawali 2004

Yusuf Qaradawi, TheIslamic Figh Opinion Difference Between Muslim Neighbor, Jakarta: Robbani Press, 1990

Dissecting Extreme Islam, Bandung: Mizan, 2001

Zubaidi, Islamic Rule and Inter-Civilization, Yogyakarta: Al-Ruzz Media Group 2007 